\title{
ANALISIS SENYAWA TERPENOID ANTIJAMUR PADA FRAKSI AKTIF EKSTRAK KULIT KAYU CEMPAKA PUTIH (MICHELIA ALBA) DENGAN METODE GAS CHROMATOGRAPHY-MASS SPECTROSCOPY
}

\author{
I G. A. G. Bawa ${ }^{1^{*}}$ dan I G. A. G. C. A. Perbhawa ${ }^{2}$ \\ I*Program Studi Kimia, Fakultas MIPA, Universitas Udayana. Jimbaran, Bali, Indonesia \\ ${ }^{2}$ Program Studi Farmasi, Fakultas MIPA, Universitas Udayana, Jimbaran, Bali, Indonesia \\ *Email: gede_bawa@unud.ac.id
}

\begin{abstract}
ABSTRAK
Ekstrak kulit kayu cempaka putih (Michelia alba) mampu menghambat pertumbuhan jamur Curvularia verruculosa yang diisolasi dari daun padi yang terserang penyakit bercak daun. Pemisahan senyawa aktif telah dilakukan dengan metode kromatografi kolom menggunakan fase diam: silica gel dan fase gerak: campuran nheksana-aseton (3:1). Hasil pemisahan diperoleh 10 fraksi gabungan, dimana 4 fraksi menunjukkan daya hambat yang sangat kuat, yaitu fraksi HAE $(31,50 \mathrm{~mm})$, HAF $(30,13)$, HAG $(48,50)$, dan HAH $(34,88)$.Komposisi senyawa terpenoid pada keempat fraksi ini dianalisis dengan GC-MS. Senyawa ledenoxid-(II) dan isoaromadendrene epoxide ditemukan hampir pada semua fraksi aktif, sedangkan spathulenol ditemukan pada fraksi HAF dan HAG. Senyawa terpenoid lainnya yang juga ditemukan adalah cis-farnesol, trans-p-mentha1(7),8-dien-2-ol, dan neoclovenoxid-alkohol hanya pada fraksi HAE, (-)-caryophyllene oxide dan tomentosin hanya pada fraksi HAG. Seluruh senyawa terpenoid yang terdeteksi merupakan senyawa dari kelompok seskuiterpen.
\end{abstract}

Kata Kunci: Ekstrak, daya hambat, Currvularia verruculossa, seskuiterpen

\begin{abstract}
The bark extract of Michelia alba was able to inhibit the growth of Curvularia verruculosa fungus which was isolated from leaf spot disease in rice. Separation of the active compound was carried out by column chromatography method using the stationary phase of silica gel and the mobile phase of a mixture of n-hexaneacetone (3: 1). Separation of the active extracts resulted in 10 combined fractions, where 4 fractions showed very strong inhibition, namely the HAE fraction (31.50 mm), HAF (30.13), HAG (48.50), and HAH (34.88). The composition of terpenoid compounds in these fractions was analyzed by Gas Chromatography-Mass Spectrometry. The compound ledenoxid (II) and isoaromadendrene epoxide werefound in almost all of the active fractions, while spathulenol wasfound in the HAF and HAG fractions. Other terpenoid compounds found werecis-farnesol, trans-p-mentha-1 (7), 8-dien-2-ol, and neoclovenoxid-alcohol in the HAE fraction, (-)caryophyllene oxide and tomentosin in the fraction of HAG. All of the detected terpenoid compounds were compounds from the sesquiterpene group.
\end{abstract}

Keywords: Michelia alba extract, inhibitory power, Curvularia verruculossa, sesquiterpenes

\section{PENDAHULUAN}

Adanya serangan penyakit bercak daun pada tanaman padi yang pada akhirnya berakibat terjadi kegagalan panen yang sangat merugikan dan meresahkan petani. Berdasarkan hasil isolasi dan identifikasi secara makroskopis, mikroskopis, dan molekuler diperoleh penyebab penyakit bercak daun tersebut adalah jamur Curvularia verruculosa (Bawa, 2019). Upaya untuk mengendalikan penyakit bercak daun saat ini masih sangat bertumpu pada penggunaan fungisida sintetik terutama setelah terjadinya penyakit. Penggunaan fungisida berbahan kimia sintetik ini secara berlebih dan berulangulang telah menyebabkan pencemaran lingkungan, menyebabkan terjadinya resistensi jamur, menimbulkan pengaruh yang tidak diinginkan pada organisme bukan target, serta meningkatkan biaya produksi bagi petani (West et al., 2003; Yoon et al., 2013). Oleh karena itu, pencarian fungisida alternatif yang murah dan ramah lingkungan mulai 
dikembangkan. Penggunaan fungisida nabati merupakan salah satu alternatif yang memenuhi kriteria tersebut, karena fungisida nabati kaya akan sumber senyawa bioaktif (Kagale et al., 2005), mudah terdegradasi di alam, tidak mencemari lingkungan, tidak memiliki residu yang bersifat fitotoksik (Omezzine et al., 2011) dan tidak berbahaya dalam penyiapan dan pemakaiannya (Rout and Tiwari, 2012).

Hasil penelitian menunjukkan bahwa ekstrak kulit kayu cempaka putih (Michelia alba) mampu menghambat pertumbuhan jamur Curvularia verruculosa secara sangat kuat (diameter zona hambatan sebesar $36 \mathrm{~mm}$ ). Ekstrak kulit kayu cempaka putih mampu menghambat pertumbuhan koloni dan pembentukan biomassa jamur $C$. verruculosa secara sempurna masing-masing pada konsentrasi 0,6 dan 1,3\%. Penelitian di rumah kaca menunjukkan bahwa ekstrak kulit kayu cempaka putih pada konsentrasi $1,5 \%$ mampu menurunkan intensitas penyakit bercak daun sebesar $62,68 \%$ dan meningkatkan hasil produksi gabah kering panen sebesar $60,62 \%$ (Bawa, 2019). Hasil penelitian ini menunjukkan bahwa ekstrak kulit kayu cempaka putih berpotensi dikembangkan menjadi fungisida nabati pengendali penyakit bercak daun Curvularia. Untuk dapat menjadikan ekstrak kulit kayu cempaka putih menjadi produk fungisida nabati, maka isolasi dan identifikasi senyawa aktif yang terkandung dalam ekstrak kulit kayu cempaka putih perlu dilakukan. Berdasarkan hasil uji fitokimia diketahui bahwa ekstrak ini mengandung senyawa golongan alkaloid, fenol/tannin, glikosida, steroid, dan terpenoid, dimana berdasarkan intensitasnya terpenoid merupakan komponen utama (Bawa, 2019).

Beberapa senyawa terpenoid khususnya kelompok seskuiterpen telah diketahui bersifat antijamur. Senyawa seskuiterpen jenis rishitin, lubimindan solavetivone merupakan fitoaleksin utama yang mengendalikan infeksi jamur pada umbi kentang (Kúc 1995). Seskuiterpen lakton jenis niveusin $B$, ethoxyniveusin $B$, dan leptocarpin yang diisolasi dari spesies-spesies Helianthus merupakan senyawa fungisidal(Spring et al.,1982). Di samping itu, senyawa costunolideand cichoralexin telah diketahui sebagai fitoaleksin masing-masing pada lettuce(Takasugi et al., 1985) and chicory (Grayer andHarborne, 1994).
Untuk mengetahui jenis senyawa terpenoid yang berpotensi menghambat pertumbuhan jamur $C$. verruculossa, maka dilakukan pemisahan senyawa-senyawa ini dengan metode kromatografi kolom dan kromatografi lapis tipis. Analisis senyawa metabolit sekunder yang terkandung pada tiap fraksi aktif dilakukan dengan metode gas chromatography-mass spectroscopy (GC-MS).

\section{MATERI DAN METODE}

\section{Bahan}

Bahan yang digunakan adalah kulit kayu cempaka putih dan jamur C. verruculossa.

\section{Alat}

Gas chromatography-mass spectroscopy (GCMS-QP2010S Shimadzu Corporation, Japan 2017).

\section{Cara Kerja \\ Ekstraksi Sampel}

Sampel kulit kayu cempaka putih (Michelia alba) setelah diambil di tempat pemotongan kayu desa Jehem, Tembuku, Bangli, dibersihkan dalam air keran yang mengalir, kemudian dikering-anginkan selama sehari. Sampel yang telah kering dipotong kecil-kecil dan kembali dikering-anginkan. Sampel diblender kering sampai menjadi serbuk. Serbuk sampel kering sebanyak 1000 gram dimaserasi dengan $2000 \mathrm{~mL}$ metanol selama 24 jam sebanyak 3 kali. Filtrat yang diperoleh digabung dan diuapkan pelarutnya dengan rotary vacuum evaporator, sehingga diperoleh ekstrak kasar (crude extracts) metanol.

\section{Uji aktivitas antijamur ekstrak kulit kayu cempaka putih (Michelia alba) dengan metode sumur difusi}

Cawan Petri yang berdiameter $9 \mathrm{~cm}$ diisi dengan 1 mlsuspensi biakan jamur $C$. verruculossa yang telah dicincang halus dan dilarutkan dalam air steril, kemudian ditambahkan $10 \mathrm{ml}$ media Potato Dextrose Agar (PDA) encer (suhu sekitar $45^{\circ} \mathrm{C}$ ) digoyang-goyang horizontal agar jamur dan media PDA tercampur merata. Setelah media memadat sebanyak dua buah sumur difusi dibuat pada setiap cawan Petri. Setiap sumur difusi diisi $20 \mu \mathrm{l}$ ekstrak kulit kayu cempaka putih. Biakan ini ditaruh pada tempat gelap 
pada suhu kamar. Pengamatan dilakukan dengan mengukur diameter zona hambatan yang terbentuk di sekitar sumur difusi.

\section{Fraksinasi ekstrak kasar kulit kayu cempaka putih}

Fraksinasi ekstrak kasar kulit kayu cempaka putih dilakukan untuk memisahkan komponen-komponen senyawa berdasarkan kelarutannya. 30 gram ekstrak kasar kulit kayu cempaka putih dilarutkan dalam $250 \mathrm{ml}$ pelarut etanol 5\% dalam air tween-80 0,5\%. Residu yang tidak terlarut kemudian dilarutkan dalam $250 \mathrm{ml}$ pelarut aseton. Larutan ekstrak etanol $5 \%$ difraksinasi secara berturut-turut dengan 3 x $100 \mathrm{ml}$ pelarut $\mathrm{n}$-heksana, kloroform dan $\mathrm{n}$ butanol, sedangkan larutan ekstrak aseton difraksinasi dengan 3 x $100 \mathrm{ml}$ secara berturutturut dengan pelarut $\mathrm{n}$-heksana dan n-butanol. Filtrat dari masing-masing fraksi diuapkan pelarutnya dengan rotary vacuum evaporator, sehingga diperoleh ekstrak n-heksana dari etanol 5\% (HE), kloroform dari etanol 5\% (CE), n-butanoldari etanol 5\% (BE) dan ekstrak etanol 5\% (E), sedangkan dari larutan ekstrak aseton diperoleh ekstrak n-heksana dari aseton (HA), ekstrak n-butanol dari aseton (BA) dan ekstrak aseton (A). Masing-masing ekstrak diuji aktivitas antijamurnya secara in vitro.

\section{Pemisahan komponen aktif dengan kromtografi kolom dan kromatografi lapis tipis (KLT)}

Ekstrak yang menunjukkan aktivitas fungisida tertinggi terhadap $C$. verruculossadipisahkan dengan kolom kromatografi. Ekstrak sebanyak 5 gram dimasukkan ke dalam kolom kromatografi yang panjangnya $59 \mathrm{~cm}$ dan diameter $3,2 \mathrm{~cm}$. Kolom tersebut sebelumnya telah diisi dengan 115 gram silika gel (Wako gel, particle size $75-150 \mu \mathrm{m})$ dan dimanpatkan selama 24 jam. Kolom dialiri eluen terbaik yang diperoleh pada kromatografi lapis tipis.Eluat ditampung tiap5 ml dan diuji kromatografi lapis tipis. Fraksi yang menunjukkan pola noda yang sama digabungkan. Tiap fraksi gabungan diuji daya hambatnya terhadap jamur $C$. verruculossa dengan metode sumur difusi.

\section{Analisis Fraksi Aktif dengan Gas Chromatography-Mass Spekstroscopy (GC- MS).}

Setiap fraksi aktif antijamur dianalisis dengan gas chromatography-mass spectroscopy (GCMS-QP2010S Shimadzu Corporation, Japan 2017); AGILENT DB-1 (CrossbondR $100 \%$ dimethylpolysiloxane) Column wtth the length of 30 meters; ID: 0.25 $\mathrm{mm}$; Film thickness of $0.2 \mu \mathrm{m}$; Helium carrier gas ; Ionizing of EI $70 \mathrm{Ev}$.

\section{HASIL DAN PEMBAHASAN}

\section{Ekstraksi dan Partisi}

Ekstraksi 1000 gram sampel menghasilkan $\pm 30 \mathrm{~g}$ ekstrak kasar metanol kulit kayu cempaka putih. Hasil partisi terhadap $30 \mathrm{~g}$ ekstrak kasar menghasilkan ekstrakHE sebesar 0,95 g; CE $(2,04 \mathrm{~g})$; BE $(3,36 \mathrm{~g})$; E $(5,06 \mathrm{~g}) ; \mathrm{HA}(6,46 \mathrm{~g})$; BA $(4,75 \mathrm{~g})$ dan A (7,02 g). Dari seluruh ekstrak ini, empat diantaranya menunjukkan daya hambat sangat kuat terhadap jamur $C$. verruculossa, yaitu $\mathrm{HE}$ $(43,8 \mathrm{~mm}), \mathrm{HA}(43,6), \mathrm{CE}(37,2)$, dan A $(32,0)$ (Gambar 1). Daya hambat ekstrak HE dan HA hampir sama, namun jumlah ekstrak HE yang diperoleh sangat sedikit, sehingga hanya ekstrak HA yang dipisahkan dengan kromatografi kolom.

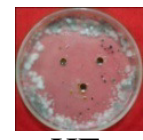

HE

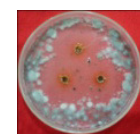

$\mathrm{CE}$

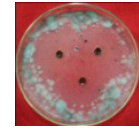

HA

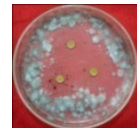

A
Daya hambat ekstrak aktif kulit kayu cempaka putih terhadap jamur $C$. verruculosa

Pemisahan ekstrak HAdengan metode kromatografi kolom menggunakan eluen nheksana-aseton (3:1) menghasilkan 10 fraksi gabungan, yang setelah diuapkan pelarutnya dengan rotary vacuum epavorator didapatkan 10 ekstrak, yaitu ekstrakHAA (0 g) karena hanya pelarut, $\operatorname{HAB}(0,4 \mathrm{~g}), \operatorname{HAC}(0,3 \mathrm{~g})$, HAD $(0,1 \mathrm{~g}), \operatorname{HAE}(0,1 \mathrm{~g}), \mathrm{HAF}(0,4 \mathrm{~g}), \mathrm{HAG}$ $(1,1 \mathrm{~g})$, HAH $(0,5 \mathrm{~g})$, HAI $(0,5 \mathrm{~g})$ dan HAJ $(1,3$ g). EkstrakHAE, HAF, HAG, dan HAH mampu menghambat pertumbuhan jamur $C$. verruculossa dengan sangat kuat (daya hambat berturut-turut sebesar 31,50; 30,13; 48,50; $34,88 \mathrm{~mm}$ ), sedangkan ekstrakHAD, HAI dan 
HAJ masuk katagori kuat $(10,00 ; 16,88$; dan $10,38 \mathrm{~mm})$. EkstrakHAG merupakan ekstrak yang paling kuat menghambat pertumbuhan jamur Curvularia verruculossa (Gambar 2).

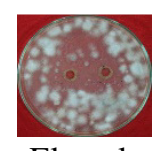

Ekstrak

HAD

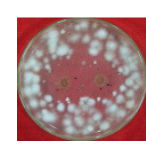

Ekstrak HAE

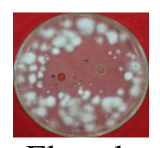

Ekstrak HAF

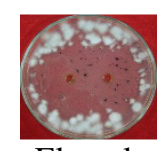

Ekstrak HAG

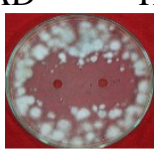

Ekstrak $\mathrm{HAH}$

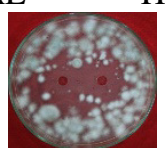

Ekstrak HAI

Gambar 2
Daya hambat ekstrak-ekstrak aktif hasil kromatografi kolom ekstrak HA

Hasil analisis kandungan senyawa metabolit sekunder ekstrak HAE, HAF, HAG dan HAH dengan metode GC-MS menunjukkan bahwa ekstrak aktif kulit kayu cempaka putihmengandung senyawa metabolit sekunder dari kelompok terpenoid (Tabel 1).

Tabel 1. Hasil analisis kandungan senyawa metabolit sekunder ekstrak aktif kulit kayu cempaka putih (Michelia alba)

\begin{tabular}{|c|c|c|c|c|}
\hline Fraksi & $\begin{array}{c}\text { Daya } \\
\text { hambat } \\
(\mathrm{mm})\end{array}$ & Jenis Senyawa & $\begin{array}{l}\text { Waktu } \\
\text { Retensi }\end{array}$ & $\begin{array}{l}\text { Konsentrasi } \\
\text { Relatif }(\%)\end{array}$ \\
\hline \multirow{5}{*}{ HAE } & 31,50 & cis-Farnesol & 12,386 & 30,52 \\
\hline & & $\begin{array}{l}\text { trans-p-Mentha-1(7),8- } \\
\text { dien-2-ol }\end{array}$ & 13,832 & 2,71 \\
\hline & & Neoclovenoxid-alkohol & 14,132 & 4,68 \\
\hline & & $\begin{array}{l}\text { Isoaromadendrene } \\
\text { epoxide }\end{array}$ & 14,229 & 9,19 \\
\hline & & Ledenoxid-(II) & 14,744 & 4,73 \\
\hline \multirow[t]{2}{*}{ HAF } & 30,13 & (+)-spathulenol & - & - \\
\hline & & $\begin{array}{l}\text { Isoaromadendrene } \\
\text { epoxide }\end{array}$ & 14,232 & 36,75 \\
\hline \multirow[t]{5}{*}{ HAG } & 48,50 & (+) spathulenol & 12,053 & 2,26 \\
\hline & & $\begin{array}{l}\text { (-)-Caryophyllene } \\
\text { oxide }\end{array}$ & 12,952 & 18,06 \\
\hline & & Tomentosin & 13,403 & 8,33 \\
\hline & & $\begin{array}{l}\text { Isoaromadendrene } \\
\text { epoxide }\end{array}$ & 14,237 & 20,81 \\
\hline & & Ledenoxid-(II) & 14,753 & 14,20 \\
\hline HAH & 34,88 & Ledenoxid (II) & 14,747 & 6,38 \\
\hline
\end{tabular}

Seluruh senyawa terpenoid yang terdeteksi merupakan senyawa seskuiterpen (C-15). Keberadaan senyawa ini di alam dapat dalam bentuk alkohol, oksida atau epoksida maupun lakton. Senyawa seskuiterpen alkohol yang terdapat pada fraksi-fraksi aktif kulit kayu cempaka putih, yaitu cis-farnesol, transp-mentha-1(7),8-dien-2-ol, dan spathulenol. Senyawa seskuiterpen oksida, yaitu ledenoxid(II) dan (-)-caryophyllene oxide; Senyawa seskuiterpen epoksida, yaitu isoaromadendrene epoxide; dan bentuk lakton, yaitu tomentosin; sedangkan neoclovenoxid-alkohol merupakan campuran oksida dan alkohol.

Keberadaan senyawa seskuiterpen pada setiap fraksi diduga kuat bertanggung jawab pada aktivitas antijamur terhadap $C$. verruculossa, karena beberapa senyawa seskuiterpen tersebut telah diketahui bersifat antijamur. Senyawa farnesol mampu menghambat pembentukan germ-tube jamur Candida albicans (Hogan et al., 2004; Wang et al., 2004). Senyawa farnesol pada konsentrasi $300 \mu \mathrm{M}$ mampu menghambat pembentukan germ-tube (tabung kecambah) jamur $C$. albicans sampai 60\% (Zhang et al. 2011). Caryophyllene oxide pada konsentrasi 5\% mampu menghambat $100 \%$ pertumbuhan jamur Trychophyton rubrum, $T$. mentagrophytes var. mentagrophytes, dan $T$. mentagrophytes var. interdigitale (Yang et al. 1999). Senyawa tomentosin yang diisolasi dari Inula viscosa mampu menghambat pertumbuhan jamur Plasmopara viticola penyebab penyakit downy mildew pada daun anggur dengan $\mathrm{ED}_{50}$ sebesar $85 \mathrm{mg} / \mathrm{ml}$ (Cohen et al. 2006).

\section{SIMPULAN}

Ekstrak kasar metanol kulit kayu cempaka putih mengandung berbagai jenis senyawa terpenoid dari kelompok seskuiterpen yang diduga kuat bertanggung-jawab pada kemampuan daya hambat terhadap pertumbuhan jamur C. verruculossa. Senyawa ini di alam dapat berada dalam bentuk alkohol, oksida atau epoksida maupun lakton.

\section{SARAN}

Untuk mengetahui jenis senyawa seskuiterpen yang mampu menghambat pertumbuhan jamur $C$. verruculossa, maka perlu dilakukan penelitian lebih lanjut untuk mengidentifikasi senyawa aktif tunggal yang terkandung dalam kulit kayu cempaka putih.

\section{DAFTAR PUSTAKA}

Bawa, I G.A.G. 2019. Senyawa Aktif dan Aktivitas Fungisida Ekstrak Kulit Kayu Cempaka Putih (Michelia alba) Terhadap Jamur Curvularia verruculosa Penyebab Penyakit 
Bercak Daun pada Tanaman Padi (Oryza sativa L.). Disertasi. Denpasar: Universitas Udayana.

Cohen, Y., Wang, W., Ben-Daniel, B.H., and Ben-Daniel, Y. 2006. Extracts of Inula viscosa Control Downy Mildew of Grapes Caused by Plasmopora viticola. The American Phytopathological Society. 96(4):417424.

Grayer, R. J. and Harborne, J. B. 1994. A Survey of Antifungal Compounds from Higher Plants, 1982-1993. Phytochemistry, 37(1): 19-42.

Hogan, D. A., Vik, A., and Kolter, R. 2004. A Pseudomonas aeruginosa quorumsensing molecule influences Candida albicans morphology. Mol. Microbiol. 54: 1212-1223.

Kagale S, Marimuthu T, Thayumanavan B, Nandakumar R, Samiyappan R. 2005. Antimicrobial activity and induction of systemic resistance in rice by leaf extract of Datura metel against Rhizoctonia solani and Xanthomonas pv oryzae. Physiological and Mole. Plant Pathol. 65: 91-100.

Kuc, J. 1995. Phytoalexins, Stress Metabolism, and Disease Resistance in Plants. Annu. Rev. Phytopathol, 33: 275-297.

Omezzine, F., Daami-Remadi, M., Rinez, A., Ladhari, A., and Haouala, R. 2011. In vitro assessment of Inula spp. organic extracts for their antifungal activity against some pathogenic and antagonistic fungi. African Journal of Microbiology Research Vol. 5(21),: 3527-3531.

Rout, S., and Tewari, S. N. 2012. Fungitoxic Spectrum of Amalaba Against Fungal Pathogens in Rice Under In Vitro. J. Biopest. 5:161-167.

Spring, O., Albert, K., Hager, A. 1982. Three Biologically Active Heliangolides from Helianthus annuus. Phytochemistry. 21(10): 2551-2553.

Takasugi, M., Okinaka, S., Katsui, N., Masamune, E., Shirata, A., Ohuchi, M.J. 1985. Isolation and Structure of Lettcinin A, A Novel Guaianolide Phytoalexin from Lactuca sativa var. capitata (Compositae). J. Chem. Soc. Chem. Commun. 621-622.

West, J.S., Bravo, C., Oberit, R., Lemaire, D., Moshou, D., McCartney, H.A. 2003. The Potential of Optical Canopy Measurement for Targeted Control of Field Crop Diseases. Annual Review of Phytopathology, 41: 593-614.

Yoon, M.Y., Cha, B., Kim, Jin-Cheol. 2013. Recent Trends in Studies on Botanical Fungicides in Agriculture, Plant Pathol J., 29: 1-9.

Yang, D., Michel, L., Chaumont, J. P and Millet-Clerc, J. 1999. Use ofcaryophyllene oxide as an antifungal agent in an in vitroexperimental model of onychomycosis. Mycopathologia, 148: 79-82,

Zhang, Y.Q., Cai, C., Yang, Y.X., and Weng, L. 2011. Blocking of Candida albicans biofilm formation bycis-2-dodecenoic acid and trans-2-dodecenoic acid. $J$. Med. Microbiol., 60: 1643-1650

Wang, L. H., He, Y., Gao, Y., Wu, J. E., Dong, Y. H., He, C., Wang, S. X., Weng, L. $\mathrm{X}$., and $\mathrm{Xu}$, J. L. 2004. A bacterial cell-cell communication signal with cross-kingdom structural analogues. Mol. Microbiol. 51: 903-912. 